\title{
PENTOSE PHOSPHATE PATHWAY
}
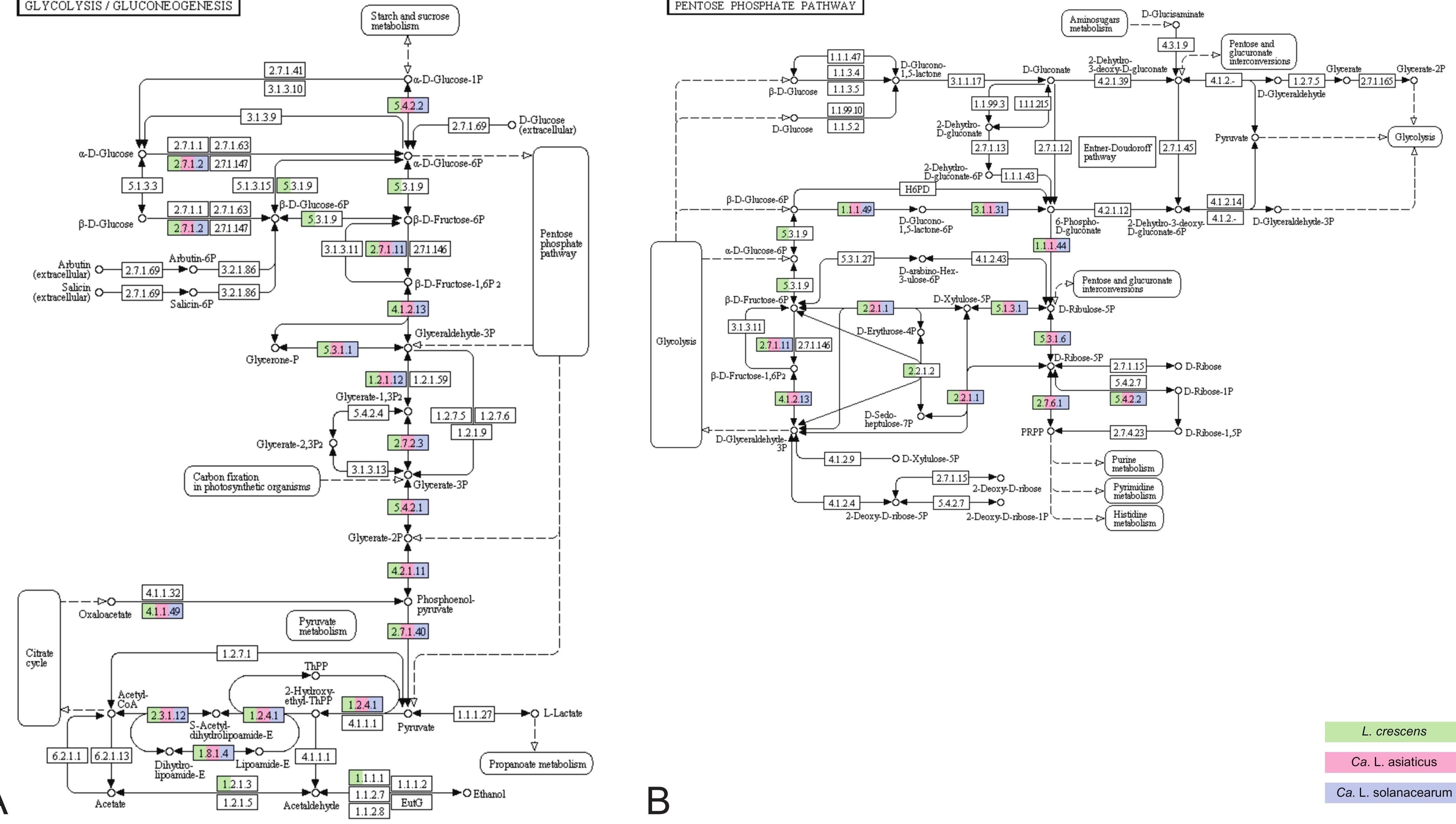

B 